\title{
Nursing Perception on Patient Safety Culture: The Latest Methodological Approaches
}

\author{
Elsa Vitale $^{1^{*}} \quad$ Francesco Germini $^{2} \quad$ Michele Massaro $^{3} \quad$ Rosa Silvia Fortunato $^{4}$ \\ 1.MSN, BSN, ASL Bari, Italy \\ 2.MSN, BSN, RN, ASL Bari, Italy \\ 3.MSN, BSN, ASL Bat, Italy \\ 4.BSN, RN, ASL Bologna, Italy
}

\begin{abstract}
Safety culture can be defined as "the values shared among organization members about what is important, their beliefs about how things operate in the organization, and the interaction of these with work unit and organizational structures and systems, which together produce behavioral norms in the organization that promote safety".

This literature review aimed to identify the latest methodological approaches quantifying patient safety culture perception among nurses. The available literature was searched from January 2018 to today . Eleven eligible works were found and analyzed and the main key concepts highlighted were: the research approaches to assess patient safety culture, the development of quantitative survey tools for data collection for further reproducibility and the levels of data aggregation for conducting data analyses.
\end{abstract}

A cohesive body of literature of evaluation tools is requiring on patient safety culture among nurses which is still limited in the current literature.

Keywords: Health Safety; Methodological Approach; Nursing Perception; Patient Safety; Safety Culture; Safety Survey.

DOI: $10.7176 / \mathrm{JHMN} / 62-12$

Publication date:May $31^{\text {st }} 2019$

\section{Introduction}

Safety culture can be described in the role of the benefits distributed among association representatives about the topics, their convictions and the interaction of these with health care systems, which collectively generate attitudinal standards in the organizations that encourage security". The recognition that safety measure performs an important task in the creation of patient security policies has allowed achievements to promote safeguard on focusing a persuasive security lifestyle. To encourage safeguard habits several healthcare policies are employed, to acquire circumstantial expertise and to raise the capability to recognize important policies for cultural innovation. While researchers have assessed studies applicable to assess organizational culture in health care and have recognized properties of devices available for evaluating patient safety climate, there has been no systematic work of instruments performing the safety climate within the healthcare context.

A key condition to ameliorate healthcare patient security is developing a suffer and helpful patient safety lifestyle to establish possible frailty and to improve policies in order to minimize incidents. The work " To Err is Human: Building a Safer Health Systems by the Institute of Medicine (IOM)" proposed patient safety as an important health theme ${ }^{5}$. The IOM research elicited studies to elaborated new systematic advances to ameliorate patient safety in healthcare contexts. Patient safeguard measure has increased importance throughout the world by becoming one of the main points in patient safety study internationally.

Patient safety culture evaluations need healthcare and non-healthcare competencies to perform self-reported surveys anonymously periodically. These questionnaires are helpful instruments to record healthcare professionals' manners, to specify domain needed immediate consideration and to trigger involvements to decrease the risk of incidents. These assessments contribute useful information on how patient security is perceived and managed in a healthcare context. Moreover, safety measures have been studied to positively influence patient safety since healthcare professionals give an account of five times more incidents due to risk knowledge.

The seminal Institute of Medicine (IOM) survey “To Err Is Human” reported that medical errors kill between 44.000 and 98.000 people in U.S. hospitals each year, while in Italy this data are until unevaluated and underestimated. The IOM committee suggested that healthcare systems develop conditions in which a safe lifestyle is a natural planning scope, becoming a prime concern, and is directed by leadership.

In return to this suggestions, healthcare systems started the slow development of patient safety, concentrating on management safety habits.

The first point is to describe patient safety lifestyle. The Agency for Healthcare Research and Quality (AHRQ) from the Health and Safety Commission of Great Britain defined security lifestyle as the safety policy of a system which is the product of individual and collective benefits, opinions, awareness, abilities, and arrangements of conduct that cause the adherence to a health system and security care".

Practically, it is less hard to define security organization than to comprehend the features that describe a 
security culture and its consequences in healthcare systems.

In this revision, patient safety culture among nursing perceptions was critically explored by identifying studies that address the methodological approach to evaluate nursing perceptions on patient safety culture. Numerous authors exposed an academic system for a security polish; however, the review provided the idea that an added complete system could be projected including a wider variety of effects. The aims of this report were to explore security lifestyle perceptions among nurses and to address future studies by developing and clarifying an ideal safety lifestyle useful to encourage nursing work in enhancing an evaluable patient safety culture.

\section{Methods}

The revision method was a meta-analysis literature reassessment in order to identify the latest methodological approaches quantifying patient safety culture perception among nurses.

The review was conducted using electronic databases Pub Med and Google Scholar from the $1^{\text {st }}$ January 2018 to today. The search policy associated selected MeSH labels and indiscriminate terms to catalogue original articles on patient safety assessments in nursing. The search was developed searched the words: "patient safety" OR "safety" OR "nursing" [MeSH]) AND ("culture of safety" OR "patient safety culture" OR "nursing perception"). A total of 98 article were filtered. All 98 abstracts were read. From these, only free full-text articles were included, which better respected the inclusion and exclusion criteria (Table 1).

Table 1. Inclusion and exclusion criteria for literature selection

\section{Inclusion criteria}

- Only free full article;

- Research article which evaluate methodological approaches on nursing perception in patient safety culture;

- Literature published only in English language;

- Literature published from 2018 to today.

\section{Exclusion criteria}

- Review studies;

- Nursing evaluation on work environmental;

- Patient safety indicators to estimate the impact of potential adverse effects on outcomes;

- Patient safety indicators used to measure hospital quality;

- Patient safety taxonomy - terminology and classification schema for near misses and adverse effects;

- Health care quality assessment;

- Patient safety indicators as performance measures;

- Nursing students' perceptions.

Finally, only 11 full-text original articles were considered in this review in order to better define the methodological approach to quantify nursing perception on patient security lifestyle (Table 2).

Table 2. Articles included in the review.

\begin{tabular}{|c|c|c|c|}
\hline Article & Methods & & \\
\hline 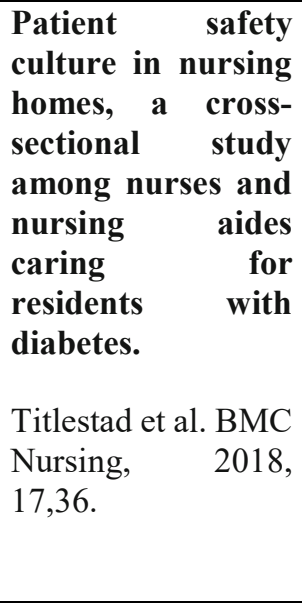 & $\begin{array}{l}\text { Cross-sectional survey design. } \\
\text { The study included } 89 \text { nursing } \\
\text { home personnel ( } 38 \text { registered } \\
\text { nurses and } 51 \text { nurse aides), } 25 \\
\text { ( } 28 \% \text { ) with advanced education, } \\
\text { at two nursing homes. Self- } \\
\text { reported questionnaire data on } \\
\text { age, profession, education and } \\
\text { work experience, diabetes } \\
\text { knowledge and familiarity with } \\
\text { diabetes guidelines were } \\
\text { collected. Nursing Home Survey } \\
\text { on Patient Safety Culture } \\
\text { instrument, with } 42 \text { items and } 12 \\
\text { dimensions was performed. }\end{array}$ & $\begin{array}{l}\text { Nurses with advanced } \\
\text { education scored higher in all } \\
\text { patient safety culture } \\
\text { dimensions than those without. } \\
\text { Statistically significant only } \\
\text { for the dimensions } \\
\text { "teamwork" and "overall } \\
\text { perceptions of resident safety". } \\
\text { Nursing personnel who were } \\
\text { familiar with diabetes } \\
\text { guidelines for older people had } \\
\text { more positive perceptions in } \\
\text { key areas of patient safety } \\
\text { culture, than those without } \\
\text { familiarity with the guidelines. }\end{array}$ & $\begin{array}{l}\text { Advanced } \\
\text { education and } \\
\text { familiarity with } \\
\text { current diabetes } \\
\text { guidelines were } \\
\text { related to adequate } \\
\text { evaluations on } \\
\text { essential areas of } \\
\text { patient safety } \\
\text { culture in nursing } \\
\text { homes. }\end{array}$ \\
\hline $\begin{array}{lr}\text { Patient } & \text { safety } \\
\text { culture: } & \text { evaluation } \\
\text { by } & \text { nursing } \\
\text { professionals. }\end{array}$ & $\begin{array}{l}\text { Cross-sectional quantitative } \\
\text { study, of the survey type, was } \\
\text { performed. The data collection } \\
\text { occurred between June and July } \\
2013 \text {. The questionnaire } \\
\text { Hospital Survey on Patient }\end{array}$ & $\begin{array}{l}\text { Among } 12 \text { dimensions } \\
\text { evaluated, only six had } \\
\text { positive response rates greater } \\
\text { than } 50 \% \text {, being the frequency } \\
\text { of event reporting }(61.4 \%) \text {, } \\
\text { organizational learning - }\end{array}$ & $\begin{array}{l}\text { positive safety } \\
\text { culture, } \\
\text { improvement } \\
\text { actions involving } \\
\text { management and }\end{array}$ \\
\hline
\end{tabular}




\begin{tabular}{|c|c|c|c|}
\hline Article & Methods & Results & Findings \\
\hline $\begin{array}{l}\text { Texto } \quad \text { Contexto } \\
\text { Enferm, } 2018, \\
27(3): e 2670016\end{array}$ & $\begin{array}{l}\text { Safety Culture was used, } \\
\text { answered by } 437 \text { professionals } \\
\text { of the nursing team, with a } \\
\text { response rate of } 100 \% \text {. }\end{array}$ & 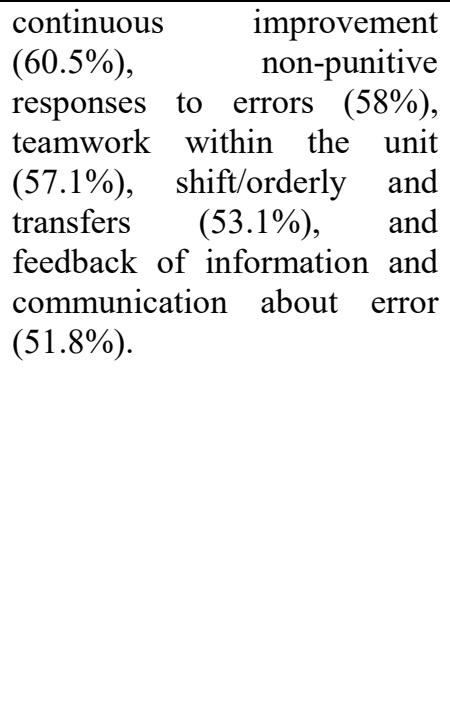 & $\begin{array}{l}\text { leadership are } \\
\text { required: } \\
\text { - general } \\
\text { perception of } \\
\text { safety; } \\
\text { - expectations } \\
\text { about the } \\
\text { supervisor/boss } \\
\text { and actions that } \\
\text { promote safety; } \\
\text { - the opening of } \\
\text { communication; } \\
\text {-support } \\
\text { hospital of } \\
\text { management for } \\
\text { patient safety and } \\
\text { teamwork } \\
\text { between units. }\end{array}$ \\
\hline $\begin{array}{l}\text { The perceptions of } \\
\text { physicians and } \\
\text { nurses regarding } \\
\text { the establishments } \\
\text { of patient safety in } \\
\text { a regional teaching } \\
\text { hospital in Taiwan. } \\
\text { Huang, CH; et al. } \\
\text { Iran J Public Health, } \\
2018,47,(6), 852- \\
860 \text {. }\end{array}$ & $\begin{array}{l}\text { An intra-organizational online } \\
\text { survey was conducted. } \\
\text { Confirmatory factor analysis } \\
\text { (CFA) was first performed on } \\
\text { the assessment of the measures } \\
\text { for patient safety culture and } 7 \\
\text { dimensions with } 33 \text { items were } \\
\text { identified. Pearson correlation } \\
\text { analysis was subsequently used } \\
\text { to examine the strength and } \\
\text { direction of the relationships } \\
\text { between } 7 \text { dimensions of patient } \\
\text { safety culture. }\end{array}$ & $\begin{array}{l}\text { A total of } 800 \text { questionnaires } \\
\text { were issued and } 405 \text { valid } \\
\text { questionnaires were collected. } \\
\text { Safety climate (SC) was } \\
\text { positively and significantly } \\
\text { related to teamwork climate } \\
\text { (TC) and perception of } \\
\text { management (PM), whereas } \\
\text { stress recognition (SR) was } \\
\text { negatively related to burnout } \\
\text { (BUR). }\end{array}$ & $\begin{array}{l}\text { Patient safety } \\
\text { culture in } \\
\text { healthcare } \\
\text { organizations has } \\
\text { been considered a } \\
\text { critical issue for } \\
\text { improving the } \\
\text { quality of } \\
\text { healthcare. }\end{array}$ \\
\hline $\begin{array}{lr}\begin{array}{l}\text { Baseline } \\
\text { assessment } \\
\text { patient } \\
\text { culture in } \\
\text { hospitals }\end{array} & \begin{array}{r}\text { of } \\
\text { safety } \\
\text { public } \\
\text { Kuwait. }\end{array} \\
& \\
\text { Ali, H.; et al. BMC } \\
\text { Health } \\
\text { Research, } \\
\begin{array}{l}\text { Services } \\
\text { 18,158. }\end{array}\end{array}$ & $\begin{array}{l}\text { This cross sectional study } \\
\text { adopted a customized version of } \\
\text { HSOPSC developed by the } \\
\text { Agency for Healthcare Research } \\
\text { and Quality. The survey targeted } \\
\text { selected public hospital staff } \\
\text { with at least one year of } \\
\text { experience. Univariate analysis } \\
\text { was utilized to obtain an } \\
\text { overview of respondent } \\
\text { demographics. The association } \\
\text { between patient safety grade and } \\
\text { the number of events reported } \\
\text { and the remaining patient safety } \\
\text { culture composites was analyzed } \\
\text { using ANOVA f-test. Four } \\
\text { regression models were } \\
\text { constructed, two adopted } \\
\text { Generalized Estimating } \\
\text { Equations and the others were } \\
\text { linear models. } \\
\text { Results were benchmarked } \\
\text { against similar initiatives in } \\
\text { Lebanon, Saudi Arabia and } \\
\text { USA. And a }\end{array}$ &  & $\begin{array}{l}\text { Study findings can } \\
\text { guide and inform } \\
\text { country level } \\
\text { strategies to } \\
\text { further improve } \\
\text { the systems } \\
\text { governing patient } \\
\text { safety practices. }\end{array}$ \\
\hline
\end{tabular}




\begin{tabular}{|c|c|c|c|}
\hline Article & Methods & Results & Findings \\
\hline & & $\begin{array}{l}\text { composites compared to } \\
\text { regional and international } \\
\text { findings. }\end{array}$ & \\
\hline $\begin{array}{l}\text { The First U.S. } \\
\text { Study on Nurses' } \\
\text { Evidence-Based } \\
\text { Practice } \\
\text { Competencies } \\
\text { Indicates Major } \\
\text { Deficits That } \\
\text { Threaten } \\
\text { Healthcare } \\
\text { Quality, Safety, } \\
\text { and Patient } \\
\text { Outcomes. } \\
\text { Melnyk, B.M.; et al. } \\
\text { Worldviews on } \\
\text { Evidence-Based } \\
\text { Nursing, 2018; } \\
\text { 15:1, 16-25. }\end{array}$ & $\begin{array}{l}\text { A cross-sectional descriptive } \\
\text { study was conducted that } \\
\text { gathered data from an } \\
\text { anonymous online survey of } \\
\text { practicing nurses throughout the } \\
\text { U.S. } \\
\text { Measures tapped Evidence } \\
\text { Based Practice (EBP) } \\
\text { knowledge, beliefs, culture, } \\
\text { mentorship, implementation, and } \\
\text { reported competency for each of } \\
\text { the } 13 \text { EBP competencies for } \\
\text { practicing nurses and an } \\
\text { additional } 11 \text { competencies for } \\
\text { advanced practice nurses. }\end{array}$ & $\begin{array}{l}\text { A total of } 2.344 \text { nurses } \\
\text { completed the survey from } 19 \\
\text { hospitals or healthcare } \\
\text { systems. } \\
\text { Overall, the nurses reported } \\
\text { that they were not yet } \\
\text { competent in meeting any of } \\
\text { the } 24 \text { EBP competencies. } \\
\text { Younger nurses and those with } \\
\text { higher levels of education } \\
\text { reported higher and more } \\
\text { statistically significant EBP } \\
\text { competency. The EBP } \\
\text { competency scores were not } \\
\text { significantly different between } \\
\text { nurses in Magnet and non- } \\
\text { Magnet designated } \\
\text { organizations. There were } \\
\text { strong positive associations } \\
\text { between EBP competency } \\
\text { with EBP beliefs and EBP } \\
\text { mentorship, a moderate } \\
\text { positive association between } \\
\text { EBP competency and EBP } \\
\text { knowledge, and a small } \\
\text { positive association between } \\
\text { EBP competency and culture. }\end{array}$ & $\begin{array}{l}\text { There is a } \\
\text { tremendous need } \\
\text { to enhance nurses' } \\
\text { skills so that they } \\
\text { achieve } \\
\text { competency in } \\
\text { EBP in order to } \\
\text { ensure the highest } \\
\text { quality of care and } \\
\text { best population } \\
\text { health outcomes. } \\
\text { Academic } \\
\text { programs should } \\
\text { ensure } \\
\text { competency in } \\
\text { EBP in students by } \\
\text { the time of } \\
\text { graduation and } \\
\text { healthcare systems } \\
\text { should set it as an } \\
\text { expectation and } \\
\text { standard for all } \\
\text { clinicians. }\end{array}$ \\
\hline 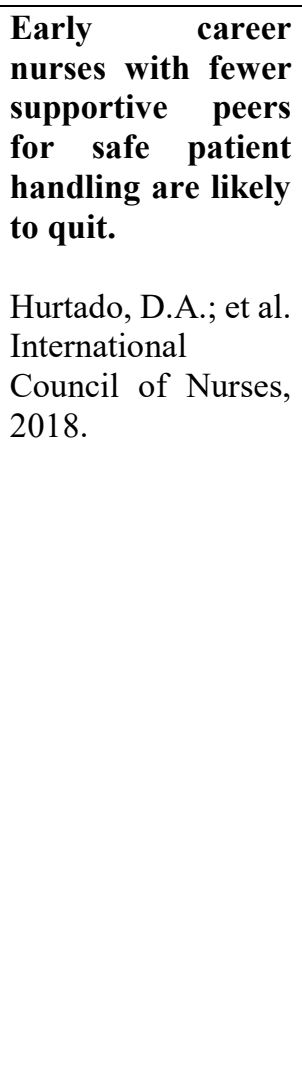 & $\begin{array}{l}\text { Convenient sampling of } \\
\text { Registered Nurses (RNs) and } \\
\text { Certified Nursing Assistants } \\
\text { (CNAs) from the } \\
\text { Medical/Surgery and Intensive } \\
\text { Care Unit of a 25-bed critical } \\
\text { access level } \\
\text { community hospital in Oregon } \\
\text { (n=49). An electronic survey } \\
\text { conducted on-site during paid } \\
\text { time in July 2016. Excluded } \\
\text { personnel were employees } \\
\text { working } \\
\text { less than } 30 \text { hours per week, in } \\
\text { non-direct-care positions } \\
\text { or with supervisory roles. A total } \\
\text { of } 35 \text { participants completed the } \\
\text { survey. }\end{array}$ & $\begin{array}{l}\text { Half of the sample worked as } \\
\text { Registered Nurses (RNs) } \\
\text { About half of the sample was } \\
\text { split during the day and night } \\
\text { shifts. During } 1 \text { year, six of } 35 \\
\text { respondents quit their jobs, for } \\
\text { a turnover rate of } 17 \% \text {. The } \\
\text { sample had a mean tenure in } \\
\text { current position of } 5.4 \text { years. } \\
\text { However, about half of the } \\
\text { sample had been employed for } \\
<2 \text { years, and another had a } \\
\text { tenure between } 2 \text { and } 4 \text { years. } \\
\text { The six employees who quit } \\
\text { had been employed for }<2 \\
\text { years. Two of the six persons } \\
\text { quit during the first year of } \\
\text { employment. Participants who } \\
\text { remained in their positions } \\
\text { nominated more peers for safe } \\
\text { patient handling advice than } \\
\text { those nurses who quit. Nurses } \\
\text { who quit their jobs received } \\
\text { the same number of } \\
\text { nominations from their peers } \\
\text { compared with nurses who } \\
\text { remained employed. Nurses }\end{array}$ & $\begin{array}{l}\text { This } r \text { study } \\
\text { suggests an } \\
\text { association } \\
\text { between lower co- } \\
\text { worker support for } \\
\text { safe patient } \\
\text { handling and } \\
\text { higher risk of } \\
\text { turnover. Further } \\
\text { research should } \\
\text { establish whether } \\
\text { increasing peer } \\
\text { safety support on a } \\
\text { hospital unit may } \\
\text { reduce nurse } \\
\text { turnover during } \\
\text { the first year of } \\
\text { employment. }\end{array}$ \\
\hline
\end{tabular}




\begin{tabular}{|c|c|c|c|}
\hline Article & Methods & Results & Findings \\
\hline & & $\begin{array}{l}\text { who quit were located at the } \\
\text { periphery of the network, } \\
\text { averaging lower two-step } \\
\text { reach than those who remained } \\
\text { employed at the end of the } \\
\text { period. The risk of quitting } \\
\text { decreased by } 15 \% \text { for each } \\
\text { additional peer that was } \\
\text { nominated as a source of safe } \\
\text { patient handling advice. The } \\
\text { risk of quitting decreased by } \\
8 \% \text { for every peer that could be } \\
\text { reached through two } \\
\text { nominated peers. Employees } \\
\text { who quit also scored lower } \\
\text { safety compliance. }\end{array}$ & \\
\hline $\begin{array}{l}\text { The long way } \\
\text { ahead to achieve } \\
\text { an effective patient } \\
\text { safety culture: } \\
\text { challenges } \\
\text { perceived by } \\
\text { nurses. } \\
\text { Farokhzadian et al. } \\
\text { BMC Health } \\
\text { Services Research, } \\
2018,18,654 \text {. }\end{array}$ & $\begin{array}{l}\text { A qualitative study with deep } \\
\text { and semi-structured individual } \\
\text { interviews was carried out using } \\
\text { a purposive sampling method to } \\
\text { select } 23 \text { nurses from four } \\
\text { hospitals affiliated with a large } \\
\text { medical university in Southeast } \\
\text { Iran. Data were analysed using } \\
\text { the conventional content } \\
\text { analysis of Lundman and } \\
\text { Graneheim. }\end{array}$ & $\begin{array}{l}\text { Data analysis reflected the } \\
\text { main theme of the study, "A } \\
\text { long way ahead of safety } \\
\text { culture". This theme includes: } \\
\text { 1) inadequate organizational } \\
\text { infrastructure, } \\
\text { 2) insufficient leadership } \\
\text { effectiveness, } \\
\text { 3) inadequate efforts to keep } \\
\text { pace with national and } \\
\text { international standards, } \\
\text { 4) overshadowed values of } \\
\text { team participation. }\end{array}$ & $\begin{array}{l}\text { There are several } \\
\text { challenges ahead } \\
\text { for cultivating an } \\
\text { effective and } \\
\text { positive safety } \\
\text { culture in } \\
\text { healthcare } \\
\text { organizations. To } \\
\text { keep pace with } \\
\text { international } \\
\text { standards, } \\
\text { healthcare } \\
\text { managers must } \\
\text { employ modern } \\
\text { methods } \\
\text { management in } \\
\text { order to overcome } \\
\text { the challenges } \\
\text { faced by the } \\
\text { institutionalization } \\
\text { of safety culture } \\
\text { and to make a } \\
\text { difference in the } \\
\text { healthcare system. }\end{array}$ \\
\hline 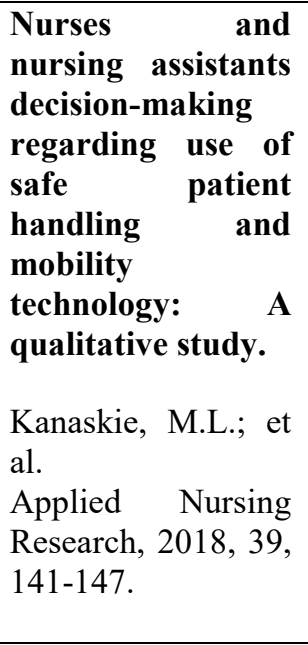 & $\begin{array}{l}\text { A qualitative descriptive study } \\
\text { was conducted. Data collection } \\
\text { consisted of four } 60 \text { min focus } \\
\text { groups. } \\
\text { Two focus groups consisted of } \\
\text { all RNs ( } \mathrm{n}=14) \text { and two } \\
\text { consisted of all NAs ( }=11) \text {. } \\
\text { Each focus group was } \\
\text { audiotaped and transcribed } \\
\text { verbatim. Transcripts were } \\
\text { coded, repeating concepts } \\
\text { identified, and codes collapsed } \\
\text { into themes and subthemes. }\end{array}$ & $\begin{array}{l}\text { Qualitative analysis revealed } \\
\text { three major themes: } \\
\text { 1) barriers to use (physical } \\
\text { barriers, knowledge and skill, } \\
\text { and unit culture, } \\
\text { 2)perceived risk, } \\
\text { 3)coordination of care. } \\
\text { Perceived risk includes: } \\
\text { 1) patient risk } \\
\text { 2) perceived risk to self. } \\
\text { Coordination of care includes } \\
\text { patient factors and } \\
\text { characteristics, assessment of } \\
\text { patient needs and abilities, and } \\
\text { interprofessional } \\
\text { collaboration. }\end{array}$ & $\begin{array}{l}\text { Interprofessional } \\
\text { team approaches } \\
\text { to patient } \\
\text { assessment and } \\
\text { care are } \\
\text { important } \\
\text { components of } \\
\text { confident decision } \\
\text { making in use of } \\
\text { SPHM } \\
\text { technology. }\end{array}$ \\
\hline How do nurses and & A cross-sectional survey was & 1787 surveys were distributed. & This \\
\hline
\end{tabular}




\begin{tabular}{|c|c|c|c|}
\hline Article & Methods & Results & Findings \\
\hline $\begin{array}{l}\text { midwives perceive } \\
\text { their preparedness } \\
\text { for } \\
\text { quality } \\
\text { improvement and } \\
\text { patient safety in } \\
\text { practice? A cross } \\
\text { sectional national } \\
\text { study in Ireland. } \\
\text { Gallen, A. et al. } \\
\text { Nurse Educ Today, } \\
2019 \text { May; } 76: 125- \\
130\end{array}$ & $\begin{array}{l}\text { undertaken across the Republic } \\
\text { of Ireland in } 2016 \\
\text { examining nurses and midwives' } \\
\text { perceptions of their knowledge } \\
\text { and skills in quality and safety } \\
\text { methods and tools, their views of } \\
\text { competence in this field using } \\
\text { the domains from the Quality } \\
\text { and Safety Education for Nurses } \\
\text { (QSEN) framework (person- } \\
\text { centered teamwork } \\
\text { care, and } \\
\text { collaboration, evidence-based } \\
\text { practice, quality improvement, } \\
\text { safety, and informatics), and } \\
\text { their participation in practice } \\
\text { related to their access to quality } \\
\text { and safety data. } \\
\text { Practicing nurses and midwives } \\
\text { (n=654) working in acute } \\
\text { hospitals and community } \\
\text { healthcare organizations who } \\
\text { were undertaking continuing } \\
\text { professional development } \\
\text { education at the time of data } \\
\text { collection. }\end{array}$ & $\begin{array}{l}\text { Data were analyzed by IBM } \\
\text { Statistical Package for the } \\
\text { Social Sciences. } \\
\text { A response rate of } 37 \% \\
\text { ( } \mathrm{n}=654 / 1787 \text { ) was achieved. } \\
\text { While respondents were } \\
\text { highly trained academically, } \\
\text { many reported a lack of } \\
\text { confidence in quality and } \\
\text { safety methods and tools and } \\
\text { QSEN competencies. } \\
\text { Frontline staff nurses and } \\
\text { midwives reported they were } \\
\text { less prepared than their mid } \\
\text { and senior level colleagues. } \\
\text { Significant numbers indicated } \\
\text { they were not engaged in } \\
\text { quality and safety in practice. }\end{array}$ & $\begin{array}{l}\text { nationwide study } \\
\text { in Ireland has } \\
\text { discovered that } \\
\text { nurses and } \\
\text { midwives perceive } \\
\text { gaps in their } \\
\text { preparedness to } \\
\text { engage in quality } \\
\text { improvement and } \\
\text { patient safety in } \\
\text { practice. To } \\
\text { safeguard patient } \\
\text { care, priority } \\
\text { should be given to } \\
\text { ensuring front-line } \\
\text { staff are } \\
\text { appropriately } \\
\text { educated, have } \\
\text { access to data, and } \\
\text { time to } \\
\text { competently } \\
\text { participate in the } \\
\text { continuous } \\
\text { improvement of } \\
\text { patient care. }\end{array}$ \\
\hline 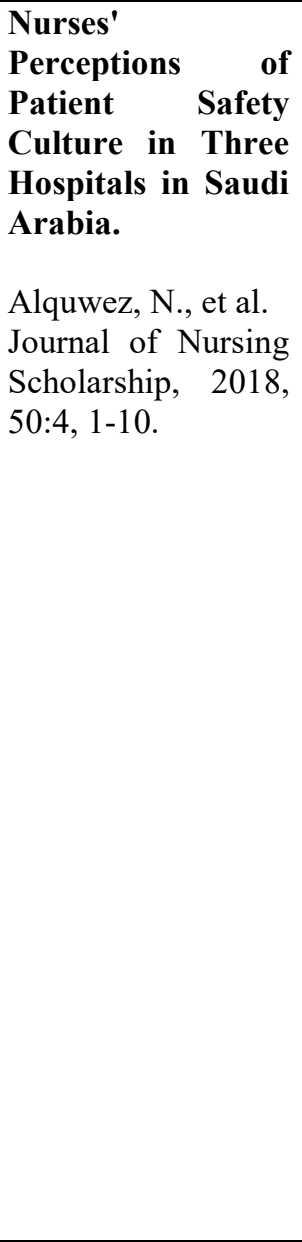 & $\begin{array}{l}\text { A descriptive, cross-sectional } \\
\text { design was adopted. } \\
\text { A convenience sample of } 351 \\
\text { nurses working in three general } \\
\text { hospitals in the central region of } \\
\text { Saudi Arabia was surveyed in } \\
\text { this study using the Hospital } \\
\text { Survey of Patients' Safety } \\
\text { Culture (HSOPSC) from } \\
\text { October 2016 to April 2017. }\end{array}$ & $\begin{array}{l}\text { From the } 12 \text { composites of the } \\
\text { HSOPSC, the nurses perceived } \\
\text { only the following two patient } \\
\text { safety areas as strengths: } \\
\text { teamwork within units and } \\
\text { organizational learning- } \\
\text { continuous improvement. Six } \\
\text { areas of patient safety were } \\
\text { identified as weaknesses, } \\
\text { namely overall perception of } \\
\text { patient handoffs } \\
\text { safety, and } \\
\text { transitions, communication } \\
\text { openness, staffing, frequency } \\
\text { of events reported, and } \\
\text { nonpunitive response to errors. } \\
\text { Nationality, educational } \\
\text { attainment, hospital, length of } \\
\text { service in the hospital, work } \\
\text { area or unit, length of service } \\
\text { in the current work area or } \\
\text { unit, current position, and } \\
\text { direct patient contact or } \\
\text { interaction were significant } \\
\text { predictors of the nurses' } \\
\text { perceived patient safety } \\
\text { culture. }\end{array}$ & 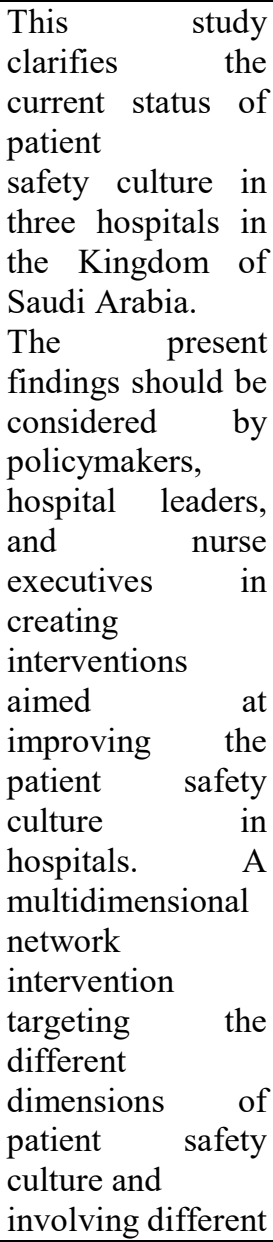 \\
\hline
\end{tabular}




\begin{tabular}{|c|c|c|c|}
\hline Article & Methods & Results & Findings \\
\hline & & & $\begin{array}{l}\text { organizational } \\
\text { levels should be } \\
\text { implemented to } \\
\text { improve patient } \\
\text { safety. }\end{array}$ \\
\hline 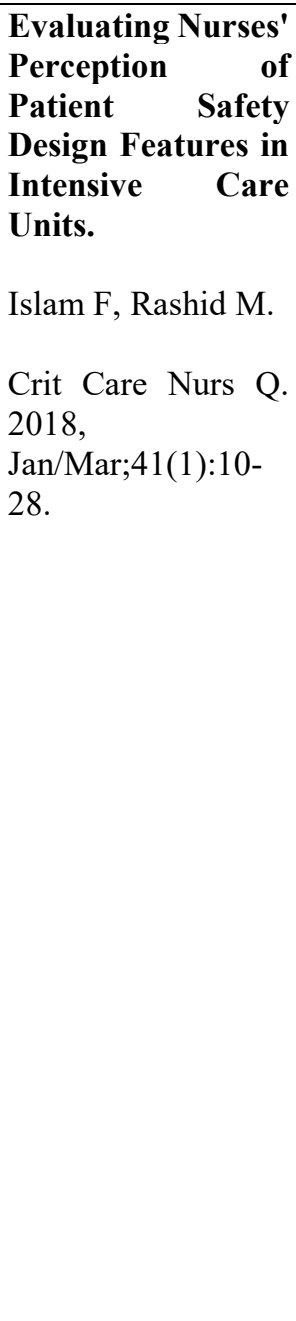 & $\begin{array}{l}\text { A methodological study was } \\
\text { conducted to test the validity and } \\
\text { reliability of the patient safety } \\
\text { scale developed by Rashid } \\
\text { (2007) for evaluating nurses' } \\
\text { perception of adult intensive care } \\
\text { unit (ICU) design features } \\
\text { related to patient safety. Data for } \\
\text { the study were collected using a } \\
\text { Web based survey instrument. A } \\
\text { link to the survey instrument was } \\
\text { posted on the Web site of } \\
\text { American } \\
\text { Association of Critical-Care } \\
\text { Nurses (AACN) for ICU nurses } \\
\text { in different US states to } \\
\text { participate. }\end{array}$ & $\begin{array}{l}\text { A sample of } 587 \text { valid } \\
\text { responses was divided into } 2 \\
\text { halves for cross-validation. } \\
\text { The first half of the sample } \\
\text { was used for exploratory factor } \\
\text { analysis and the second half } \\
\text { for confirmatory factor } \\
\text { analysis. This method was } \\
\text { applied to identify any latent } \\
\text { factor structure in the PS scale. } \\
\text { Based on the factor analyses, } 4 \\
\text { relevant PS subscales- } \\
\text { Efficient Work Process, } \\
\text { Patient Room, Accessibility } \\
\text { and Visibility, and Maintain } \\
\text { Sterility-were identified. } \\
\text { These PS subscales were used } \\
\text { to investigate whether ICU } \\
\text { unit characteristics, nurse } \\
\text { characteristics, and hospital } \\
\text { type affected nurses' } \\
\text { perception of ICU design } \\
\text { features in relation to patient } \\
\text { safety. }\end{array}$ & $\begin{array}{l}\text { Nurses' } \\
\text { perception of } \\
\text { ICU design } \\
\text { features related to } \\
\text { patient safety can } \\
\text { be influenced by } \\
\text { such factors as } \\
\text { nurse } \\
\text { characteristics and } \\
\text { unit } \\
\text { characteristics. } \\
\text { When using the } \\
\text { scales, therefore, } \\
\text { the designers can } \\
\text { be aware of the } \\
\text { influence of these } \\
\text { external factors on } \\
\text { nurses' } \\
\text { perception. It is } \\
\text { hoped that the PS } \\
\text { subscales } \\
\text { evaluating } \\
\text { nurses' perception } \\
\text { of ICU physical } \\
\text { environmental } \\
\text { features related to } \\
\text { patient safety } \\
\text { would help } \\
\text { designers and } \\
\text { health personnel make } \\
\text { better ICU design } \\
\text { choices. }\end{array}$ \\
\hline
\end{tabular}

\section{Results}

Studies effectively described nurses perception on patient security lifestyle were selected. By considering these studies and their results it was shown that patient security habits increased among nurses perception with the growth of nurses competences and culture of them.

\subsection{Description of the studies}

In the first article considered, written by Titlestad et al., the nursing awareness in patient safety measure was assessed with the participants' profession education associations. For this aim, the Nursing Home Survey on Patient Safety Culture (NHSPSC) was used to assemble values on the members' awareness. The NHSPSC was promoted in 2008 by the Agency for Healthcare Research and Quality to assess patient safeguard system among nursing homes personnel. The questionnaire comprised 42 items specified into 12 areas with three to four items in each. The answers range values for each of points were from "strongly disagree" to "strongly agree" and from "not applicable/do not know" to "every time applicable". Moreover the NHSPSC contained also two questions on general opinion on the patient safeguard culture in the nursing home and the number of reported adverse events in the past years. Individual dimension scores varied from 0 to 100 , where high values suggested positive response. The results section showed a positive statistical significance in communication openness enforced by nursing supports and statistically significance in nursing patient security perceptions correlated with advanced nursing 
education. No significant differences were evaluated in the other different areas.

In the study of da Costa et al. the data collection was performed employing the Survey on Patient Safety Culture (HSOPSC) questionnaire, too. The purpose of the survey was to measure the dimensions associated with the security habits, used in several countries of the world and to address the dimensions of safety culture in the individual scope, in the units, and in the hospital scope. The items were quantified using the Likert scale, whose categories are of agreement degree for the 12 dimensions. Each dimension was evaluated according to the percentage of positive responses, and the percentage obtained by calculating the combination of the two highest categories of response; of each dimension, the two lowest categories indicate negative results concerning culture; the middle category shows neutrality. The questions related to the number of incidents communicated and the concept given to the institution regarding patient safety by the servers were presented with their relative frequency of responses. Regarding the schooling level, most of the population of the study has completed higher education. However, when analyzing the professional category, there is a predominance of nursing technicians. It is also observed that most of the participants work in clinical and surgical hospitalization units for women and men, followed by intensive care unit, and emergency room. Among the participants, there was interaction or direct contact with the patients.

The items with worse ratings in the dimensions, that was, with a percentage of positive responses lower than $33.3 \%$, brought concern: changes in the shift or orderly were problematic for patients $(31.8 \%)$; the sufficient number of professionals to meet the workload (16.9\%); the professionals who considered that their errors, mistakes or failures could be used against them; the supervisors who demanded the work to be accomplished more quickly when the pressure increases; the supervisor/manager did not give enough attention to patient safety problems that occur repeatedly; the fact that patient safety was never compromised due to the greater amount of work to be completed; the professionals felt free to question the decisions or actions of their superiors; professionals who were afraid to question when something was not right; professionals who were informed about changes implemented from the event reports; and the professionals who felt free to question the decisions or actions of their superiors. The dimension with the fewest positive responses was the Opening of the communication. The results showed, in general, that the evaluation of the workers in relation to the patient's safety in the institutions is not positive.

In the Huang et al. work the Chinese Safety Attitudes Questionnaire (CSAQ) advanced by Taiwan Joint Commission on Hospital Accreditation (TJCHA) was developed to assess patient safeguard organization in Taiwan by measuring physicians and nurses perceptions on patient security in the regional hospital. Seven patient safety aspects with 39 points were assessed by using frequency data evaluation. For each question the Likert scale was used, where answers ranges were represented from strongly disagree to strongly agree, respectively. Furthermore, burnout was evaluated applying 9 extra questions. The results evidenced that security climate was positively and significantly reported to teamwork environment and management perception, while stress perception was negatively referred to burnout. Additionally, patient safety habit in healthcare systems has been appreciated as an important issue for ameliorating the quality of wellbeing.

In the Ali et al. study 16 hospitals in Kuwait were considered and the HSOPSC tool was used. A total of 12.871 employees fulfilled the questionnaire. The positive dimensions reported were "Teamwork within units", "organizational learning-continuous improvement", "management support for patient safety", "supervisor/manager expectations", "actions promoting patient safety", "feedback and communication about error". The other seven areas can be considered as needing enhancement, specifically: "teamwork across units", "handoffs and transitions", overall perception of patient safety, "frequency of events reported", "communication openness", "staffing" and "non-punitive response to error". All these aspects were evaluated. The great responses were addressed to the hospital ameliorating patient security. Other effectiveness dimensions were: teamwork, working together as a team. The aspects which was assessed as low concerned the dimensions on non-punitive answer to mistake because personnel were afraid that their errors were associated with their personnel profiles and their mistakes were hold against them. The dimension of communication openness was also considered to be a dimension needing increase in order to authorize the staff to make decisions or actions. The results of this research supported that incidents reporting with improve healthcare safety system. It was clearly demonstrated the importance to improve health professional report on negatively events in order to ameliorate the safety organization. The three positive important aspects security system were defined: a just culture, a reporting culture, and a learning culture, where signalizing depend by a nonpunitive condition where healthcare professionals feel free to identify negative events.

In the Melnyk et al. article the U.S. nursing evidence based practice competency was evaluated. An anonymous online questionnaire on knowledge, beliefs, culture, mentorship, implementation, and reported competency for each of the 13 Evidence Competencies (EC) for practicing nurses and an additional 11 competencies for advanced practice nurses was administered. The results indicated that nurses did not consider the evidence based practice competencies as essential in their practice. The University prepared younger nurses in the competencies than older nurses, while not more in the practice field. These highlights underlined the 
importance of evidences in supporting quality and security of care.

In the Hurtado et al. work was compared nurses who had fewer low grade of preparation on patient security system with nurses who had more supportive culture. The sample size was small. This study explored that young professional nurses who worked at least 2 years and had low knowledge on patient safety culture presented a higher risk of fairly than nurses with more supporting awareness. Moreover, social encouragement among colleagues may influence turnover thanks to the increase of participation with the social and safety organization system. Findings approved this environment, and social encouragement among colleagues was very important for assigning instruction or details on safeguard patient care, on complete methods. Additionally, the appropriate safety methods were included in the improvement of job achievement. The increase in patient safety supported resources was very important for nurses allowing them to operate in a collaborative safe patient environment.

In the Farokhzadian article et al. a semi-structured, individual, face-to-face, in-depth interviews in clinical nursing and patient safety work matters. Questions were collected after describing research purpose to participants. All meetings began with an open answer concerning the interviewers to illustrate their patient security environment. All interviews were audio-registered with the participants' permission and then written. Twenty-three interviews were collected. Data collected exposed the current merging security lifestyle in Iranian hospitals, where there were a lot of changes to plan in order to organize a safeguard culture. Furthermore, data showed negative influence in nursing safety procedures. According to nurses' perception, the risk to harm patients, staff, and organizations was increasing by "shortage of resources", "weakness of the staff's professional competence and empowerment", and "unfavourable work condition and unsafe environment". These conditions decreased also the institutionalization of an effective safety culture. This research also aimed to establish effective safety system contexts thanks to the nursing experiences in order to achieve an effective and positive safety culture.

In the Kanaskie et al. study decision-making concerning use of safe patient handling and mobility (SPHM) technology among registered nurses (RN) and nursing assistants (NA) was evaluated in order to improve education programs and procedural enhancements. Answers regarded how employers decided to use SPHM tool in order to make the right decision for safeguard patient condition. A qualitative descriptive study was performed and four 60 min focus groups were conducted. Each focus group was audiotaped, transcribed, and coded. Qualitative analysis showed three major areas: "barriers to use", "perceived risk", and "coordination of care". The results increased new learning in management of SPHM technology underlying the importance of the interprofessional team approaches to patient evaluation and care system.

In the Gallen et al. study a cross-sectional survey was undertaken across the Republic of Ireland in 2016, examining nurses and midwives' perceptions of their knowledge and skills in quality and safety methods and tools, their views of competence in this field using the domains from the Quality and Safety Education for Nurses (QSEN) framework (person-centered care, teamwork and collaboration, evidence-based practice, quality improvement, safety, and informatics), and their participation in practice related to their access to quality and safety data. response rate of $37 \%(n=654 / 1787)$ was achieved. While respondents were highly trained academically, many reported a lack of confidence in quality and safety methods and tools and QSEN competencies. Frontline staff nurses and midwives reported they were less prepared than their mid and senior level colleagues. Significant numbers indicated they were not engaged in quality and safety in practice. This first nationwide study in Ireland has discovered that nurses and midwives perceive gaps in their preparedness to engage in quality improvement and patient safety in practice. To safeguard patient care, priority should be given to ensuring front-line staff are appropriately educated, have access to data, and time to competently participate in the continuous improvement of patient care.

In the Alquwez et al. study a convenience sample of 351 nurses working in three general hospitals in the central region of Saudi Arabia was surveyed by using the Hospital Survey of Patients' Safety Culture (HSOPSC) from October 2016 to April 2017. From the 12 composites of the HSOPSC, the nurses perceived only the following two patient safety areas as strengths: teamwork within units and organizational learning-continuous improvement. Six areas of patient safety were identified as weaknesses, namely overall perception of patient safety, handoffs and transitions, communication openness, staffing, frequency of events reported, and nonpunitive response to errors. Nationality, educational attainment, hospital, length of service in the hospital, work area or unit, length of service in the current work area or unit, current position, and direct patient contact or interaction were significant predictors of the nurses' perceived patient safety culture. The findings in this study clarify the current status of patient safety culture in three hospitals in the Kingdom of Saudi Arabia and it should be considered by policymakers, hospital leaders, and nurse executives in creating interventions aimed at improving the patient safety culture in hospitals. A multidimensional network intervention targeting the different dimensions of patient safety culture and involving different organizational levels should be implemented to improve patient safety.

Finally, in the Islam and Rashid study a methodological study was conducted to test the validity and reliability of the patient safety (PS) scale developed by Rashid (2007) for evaluating nurses' perception of adult intensive care unit (ICU) design features related to patient safety. Data for the study were collected using a Web based survey instrument. A link to the survey instrument was posted on the Web site of American Association of Critical- 
Care Nurses (AACN) for ICU nurses in different US states to participate.

A sample of 587 valid responses was divided into 2 halves for cross-validation. The first half of the sample was used for exploratory factor analysis and the second half for confirmatory factor analysis. This method was applied to identify any latent factor structure in the PS scale. Based on the factor analyses, 4 relevant PS subscales were identified, as: Efficient Work Process, Patient Room, Accessibility and Visibility, and Maintain Sterility. These PS subscales were used to investigate whether ICU unit characteristics, nurse characteristics, and hospital type affected nurses' perception of ICU design features in relation to patient safety. The study shows that nurses' perception of ICU design features related to patient safety can be influenced by such factors as nurse characteristics and unit characteristics. When using the scales, therefore, the designers can be aware of the influence of these external factors on nurses' perception. It is hoped that the PS subscales evaluating nurses' perception of ICU physical environmental features related to patient safety would help designers and health care personnel make better ICU design choices.

\section{Findings}

This review aimed to identify the latest methodological approaches in order to quantify nursing perception on patient safety culture. Main key concepts highlighted in this review were:

- the research methods to assess patient security organization;

- the advance of quantitative methods in data collection for other reproducibility;

- the standards of data managing analyses.

With regard to the research methods to evaluate patient safety organization, this revision has disclosed that in the hospital environment the common method adopted was the cross-sectional quantitative survey by using the HSOPSC questionnaire. Other studies considered used write or audio tapped strategies in the semi-structured focus group or face-to-face interview.

Therefore, only a qualitative or quantitative approach do not fully express the patient safeguard lifestyle organization and the manner to manage it in order to better ameliorate this condition.

Thus, mixed methods approaches were assessed as a valid substitute method of evaluating security environment.

Additionally, the self-administered questionnaire methods for data collection was the most used with the focus group interview.

The HSOPSC survey method was the quantitative tool more adopted in the main approaches that have been proven to be psychometrically implications. The very important goal in the safeguard system is to identify a quantitative tool which could allow the reproducibility in methodology of data collection and the comparison of findings.

Future studies need to improve the security assessment tools with a standardized method. Therefore, a methodical approach was needed to review psychometric properties of all patient safety culture assessment tools.

Moreover, in all studies considered emerged the necessity of a non punitive culture to mistake in order to encourage nurses to report more events, which did not kept in their personnel files.

Furthermore, the results of the present review have to be understood heedfully. In fact, there were considered only two electronic databases for the articles research and works published in other databases may have been escaped. Additionally, only articles published in English language were considered, possibly resulting in overlooking instruments that were implemented and assessed in other languages and cultures.

A cohesive body of literature of evaluation tools is requiring on patient safety culture among nurses which is still limited in the current literature. Until more evidence is available, administrators and policymakers should be cautious in the interpretation of these surveys.

\section{Acknowledgement}

The authors gratefully acknowledge all studies' authors included in this review for their commitment in this field.

\section{References}

Ali H., Ibrahem S.Z., Al Mudaf B., Al Fadalah1 T., Jamal D., El-Jardali F. Baseline assessment of patient safety culture in public hospitals in Kuwait. BMC Health Services Research. 2018; 18:158.

Alquwez, N., et al. Nurses' Perceptions of Patient Safety Culture in Three Hospitals in Saudi Arabia. Journal of Nursing Scholarship, 2018, 50:4, 1-10.

da Costa D. B., Ramos D, Gabrie C.S., Bernardes A. Patient safety culture: evaluation by nursing professionals. Texto Contexto Enferm. 2018; 27(3):e2670016.

Farokhzadian J., Nayeri N.D., Borhani F. The long way ahead to achieve an effective patient safety culture: challenges perceived by nurses. BMC Health Services Research. 2018; 18: 654.

Gallen, A. et al. How do nurses and midwives perceive their preparedness for quality improvement and patient safety in practice? A cross sectional national study in Ireland. Nurse Educ Today, 2019 May;76:125-130 
Health and Safety Commission Advisory Committee on the Safety of Nuclear Installations. Organizing for safety: Third report of the ACSNI study group on human factors. Sudbury, UK: HSE Books. 1993.

Hellings J., Schrooten W., Klazinga N., Vleugels A. Challenging patient safety culture: survey results. Int. J. Health Care Qual. Assur 2007; 20 (7): 620-632.

Huang C.H., WU H.H., Chou C.Y., Dai H., Lee C.Y. The perceptions of physicians and nurses regarding the establishments of patient safety in a regional teaching hospital in Taiwan. Iran J Public Health. $2018 ; 47$ (6): $852-860$

Hurtado D.A., Heinonen G.A., Dumet L.M., Greenspan S.A. Early career nurses with fewer supportive peers for safe patient handling are likely to quit. International Council of Nurses. 2018.

Institute of Medicine.To Err is human: Building a safer health system. Washington, DC, 1999: National Academies Press. https://doi.org/10.17226/9728. accessed August 2018.

Islam, F.; Rashid, M. Evaluating Nurses' Perception of Patient Safety Design Features in Intensive Care Units. Crit Care Nurs Q. 2018, Jan/Mar;41(1):10-28.

Kanaskie M.L., Snyder C., et al. Nurses and nursing assistants decision-making regarding use of safe patient handling and mobility technology: A qualitative study. Applied Nursing Research. 2018; 39: 141-147.

Kohn L.T., Corrigan J.M., Donaldson M.S. To Err Is Human: Building a Safer Health System. National Academy Press, Washington, 1999.

Kohn L.T., Corrigan J.M., Donaldson M.S. To err is human: Building a safer health system. Washington, DC: National Academy Press. 2000.

McCarthy D., Blumenthal D. Stories from the sharp end: case studies in safety improvement. Milbank Q. 2006; 84 (1): 165-200.

Melnyk B.M., Gallagher-Ford L., Zellefrow C., Tucker S., Bindu T. The First U.S. Study on Nurses' EvidenceBased Practice Competencies Indicates Major Deficits That Threaten Healthcare Quality, Safety, and Patient Outcomes. Worldviews on Evidence-Based Nursing. 2018; 15 (1): 16-25.

Nieva V.F., Sorra J. Safety culture assessment: a tool for improving patient safety in healthcare organizations. Qual. Saf. Health Care. 2003; 12 (Suppl. 2): ii17-ii23.

Singer S., Lin S., Falwell A., Gaba D., Baker L. Relationship of safety climate and safety performance in hospitals. Health Serv. Res. 2009; 44: 399-421.

Titlestad I., Haugstvedt A., Igland J., Graue1 M. Patient safety culture in nursing homes, a cross-sectional study among nurses and nursing aides caring for residents with diabetes. BMC Nursing. 2018; 17:36. 